\title{
Relation between Poaceae pollen concentrations and meteorological factors during 2000-2010 in Timisoara, Romania
}

\author{
Nicoleta lanovici* \\ Department of Biology and Chemistry, Faculty of Chemistry, Biology and Geography, West University of Timisoara, Pestalozzi Street 16, 300115 Timisoara, Romania
}

\begin{abstract}
This paper presents the results of Poaceae pollen seasons from 2000-2010 in Timisoara, Romania. Airborne Poaceae pollen concentrations was high. An increasing trend in the annual totals was observed. The longest pollen season was recorded in the year 2000. The period in which the Poaceae pollen count exceeded the threshold value of 30 grains $/ \mathrm{m}^{3}$ lasted from 9 to 46 days. The present study analyzed the dynamics of pollen seasons in relation to meteorological factors. On the basis of Spearman's correlation test, the strongest positive correlation was found between the Poaceae pollen counts and temperature; and sunshine hours. Daily average relative humidity, atmospheric pressure and precipitation had a negative effect. A multiple regression analysis was applied to determine how much of the total variance in Poaceae pollen counts can be explained by meteorological parameters. The coefficient of determination ranged from 0.245 to 0.460 . Our data illustrate the contrasting effects of temperature, wind, relative humidity and rainfall on the concentration of pollen in the air. The optimum conditions for Poaceae pollen release occur during late spring and early summer. The Poaceae pollen remains one of the major aeroallergens in Timisoara area.
\end{abstract}

Keywords: aeroallergen; pollinosis; Poaceae; contrasting effects; Timisoara; meteorological factors

\section{Introduction}

The Poaceae (Gramineae, grasses) family is one of the largest vascular plant families, comprising between 650-785 genera [1]. The grass family includes $>10000$ species with a cosmopolitan distribution and occupies an enormous range of habitats [2]. The Poaceae is also one of the most economically (as cereals and feed for domesticated animals) and ecologically (accounting for $25-45 \%$ of the world's vegetation) relevant plant family $[3,4]$. Some of them are ornamental and medicinal plants [5]. Grasses include the three most important crops in the world (Triticum aestivum, Zea mays, Oryza sativa) and several productive species with great biofuel potential [6]. They are described as plants that have achieved evolutionary success [7].

The Poaceae species grow in different habitats [8]. Most representatives are anemophilous species that produce and release large amounts of pollen grains. The Poaceae pollen is one of the most important aeroallergen sources worldwide, with a well-known phenomenon of cross-reactivity among the species $[9,10]$. Poaceae pollen can also cross-react with food like beans, peas, cereals, peanut, melon, watermelon, carrot, and celery $[9,11]$. Prophillines can be responsible for

\footnotetext{
*Email: nicole_ianovici@yahoo.com
}

Handling Editor: Agnieszka Grinn-Gofroń the cross-reactions between the allergens of Poaceae pollen and the allergens of edible vegetables [12]. Thirteen pollen allergen groups have been described to date. Clinically, group 1 allergens are the most important, followed by group 5 allergens. Other clinically relevant allergens are those of groups 2, 3, 4 and 13 [13]. A variety of pollen-producing Poaceae have been recognized as allergenic, including Lolium perenne, Poa pratensis, Phleum pratense, Dactylis glomerata, Holcus lanatus and Cynodon dactylon. Poaceae pollen is the main cause of pollinosis in many European countries, North America and in parts of Australia [14-19]. Until 2000, Poaceae pollen was known as a leading cause of respiratory allergies in Romania, having negative effects on quality of life of allergy sufferers [20]. Approximately 85 genera of grasses can be found in Romania [5].

Modern aerobiological investigations using daily volumetric monitoring of atmospheric pollen began in Romania in 1999. Faur and Ianovici [21] used a volumetric method for the first time in a Romanian study during their investigation of atmospheric pollen grains in the city of Timisoara. The spectrum of air particles causing allergic rhinitis (known as hay fever or pollinosis) and asthma is rather well known. Pollinosis is the most common allergic disorder. The clinical manifestations of pollinosis are related to the composition, timing and abundance of airborne allergenic material, together with other environmental and genetic risk factors. The severity of the symptoms depends in part on the 
frequency of exposures and on the amount of pollen per exposure [22]. There are regional differences in occurrence and allergenicity of pollen. Allergenic pollen has been identified in many flowering plant species, including grasses, weeds and trees species. Airborne pollen dynamics provides valuable information in choosing diagnosis and treatment methods for pollinosis, reducing their cost and imposing new prophylactic measures. This information can also be useful to producers of extracts and allergenic vaccines, who should focus on the local presence of potentialy allergenic plant species during manufacturing of their products [23]. Changes in the allergen content of the air should be observed to react early enough by making changes in diagnostic and therapeutic measures whenever a new allergen should appear. Pollen grains of allergenic taxa occur in the atmosphere of Timisoara in large quantities from early February until late October. In the first months, the pollen originated from anemophilous trees prevails, while in the last months the pollen from anemophilous herbaceous plants is detected. The classification of plant species into the groups of trees, grasses and weeds reveals that airborne tree pollen was found only in March and April, then in May and June the grass and weed pollen occurred, whereas an absolute predominance of weed pollen was recorded in July, August and September. The long Poaceae pollen season, as found by Ianovici [24], is determined by the number of species and their various pollination time. For sensitive people, the threshold value is 30 grains $/ \mathrm{m}^{3}$, above which the symptoms of pollinosis occur [16]. After Ambrosia artemisiifolia, Poaceae discharges the second biggest amount of pollen of all taxa $[25,26]$. Knowledge about daily, seasonal and annual fluctuations in airborne pollen in any geographical area is essential for diagnosis, therapy and prophylaxis of allergic rhinitis [27].

The effect of climate on Poaceae pollen concentrations in the Timisoara area is less well known [5]. Apart from the specific phenological rhythm, weather and habitat conditions are the most important factors determining the dispersion and content of pollen in the atmosphere. Also, the variability in Poaceae pollen seasons is related to the dry deposition due to gravity, washout by precipitation, resuspension by updrafts, regional and long distance transport of pollen, and anthropogenic factors [28-30].

The results of an eleven-year study on airborne grass (Poaceae) pollen in Timisoara are presented in this article. The aim of this study was to compare the 2000-2010 pollen seasons and to determine day-to-day and yearly pollen variation as well as the effect of some meteorological parameters on Poaceae atmospheric pollen concentrations.

\section{Material and methods}

Timisoara is a city of approximately 300000 people and typical urban development. It is one of the most important administrative, cultural, academic and industrial centers of Romania $\left(45^{\circ} 45^{\prime} \mathrm{N} 21^{\circ} 13^{\prime} \mathrm{E}\right)$. The city is situated in the western region of Romania at an altitude of 88 meters above sea level. The climate is temperate continental moderate, which characterizes the southeastern part of the Panonic Field. The urban landscape and its surroundings consist of ruderal vegetation, forests, semi-natural communities of grasses, and anthropomorphic habitats. Several new taxa have been introduced which could have allergenic potential [20].

The research was carried out by means of the volumetric method using a Lanzoni trap. The samples were examined using a light microscope at $400 \times$ magnification. All identified grass pollen grains were presented as one taxon, i.e., the Poaceae family. Pollen grains were counted along 4 longitudinal transects. The Poaceae pollen counts were converted to atmospheric pollen grains concentration $/ \mathrm{m}^{3}$ of air in $24 \mathrm{~h}$ (expressed as APG/ $/ \mathrm{m}^{3}$ ). We did not apply the cumulative sum methods, threshold value methods or percentage methods to calculate the pollen season length. We took into consideration all days when the pollen was present in the air. The linear trend was calculated by the determination coefficient $\left(R^{2}\right)$. Skewness and kurtosis were also calculated. The statistical dependence between pollen concentration and meteorological factors was determined by Spearman's test. The significance was calculated for $P<0.05$. The correlation coefficients between atmospheric pollen grains concentration and daily meteorological parameters (mean daily average temperature expressed in ${ }^{\circ} \mathrm{C}$; maximum temperature in ${ }^{\circ} \mathrm{C}$; minimum temperature in ${ }^{\circ} \mathrm{C}$; relative humidity in $\%$; mean wind speed expressed in $\mathrm{m} / \mathrm{s}$; daily maximum wind speed expressed in $\mathrm{m} / \mathrm{s}$, atmospheric pressure in millibars; sunshine hours in $\mathrm{h}$; quantities of precipitation in $\mathrm{L} / \mathrm{m}^{2}$ ) were analyzed. The meteorological data for Timisoara were obtained from the records of the National Meteorological Administration. In addition to Spearman's correlation test, a multiple regression analysis was performed to determine how much of the total variance in these pollen counts can be explained by meteorological parameters. The aim was not to develop a predictive model, but rather to give information about factors that might control the dispersion of Poaceae pollen and its concentrations.

\section{Results}

In Timisoara and its neighboring areas, grass pollen is considered to be a frequent cause of sensitization. During the study period, the Poaceae pollen concentration dynamics differed. The variations in annual pollen sums of Poaceae seasons are shown in Tab. 1. The lowest annual total concentration was recorded in 2006 and the highest one in 2010. The annual sums of Poaceae pollen ranged 1882-3871 pollen grains. The mean annual pollen count during the studied period (2000-2010) was 2540.9 pollen grains. The seasonal maximum daily count showed great variation between years and varied $42-134 \mathrm{APG} / \mathrm{m}^{3}$. The diurnal Poaceae pollen counts were over the threshold value on 8-46 days, which means significant pollen release in the air. The pollen seasons lasted from 153 days in 2003 to 185 days in 2000. The average pollen season duration was 171.3 days. In all study years, the initial occurrence of grass pollen in the atmosphere was recorded in April and the end of the pollen season generally in the first half of October. Usually small amounts of airborne Poaceae pollen are present at the start and end of the seasons. Blooming starts at different dates from year to year. In 2005 the season started later (3rd 
Tab. 1 Selected values characterizing Poaceae pollen seasons in Timisoara during 2000-2010.

\begin{tabular}{cccccccccccc}
\hline Year & Max & Sum & Std. error & Stand. Dev & Skewness & Kurtosis & $\begin{array}{c}\text { Onset of } \\
\text { the pollen } \\
\text { season }\end{array}$ & $\begin{array}{c}\text { End of } \\
\text { the pollen } \\
\text { season }\end{array}$ & $\begin{array}{c}\text { Days when } \\
\text { Poaceae } \\
\text { pollen was } \\
\text { present in } \\
\text { the air }\end{array}$ & $\begin{array}{c}\text { No. of days } \\
\text { with pollen } \\
\text { concentrations } \\
\text { higher than 30 } \\
\text { APG/m }\end{array}$ \\
\hline 2000 & 64 & 2365 & 0.4871609 & 9.307196 & 2.217968 & 7.598831 & $04-13$ & $10-14$ & 185 & 9 \\
2001 & 63 & 2939 & 0.661914 & 12.64585 & 1.809381 & 2.830455 & $04-16$ & $10-10$ & 178 & 34 \\
2002 & 69 & 2230 & 0.6024038 & 11.50891 & 2.576054 & 7.384698 & $04-17$ & $10-06$ & 173 & 21 \\
2003 & 49 & 2195 & 0.50357 & 9.620681 & 1.75289 & 2.579617 & $04-29$ & $09-28$ & 153 & 13 \\
2004 & 57 & 2203 & 0.547836 & 10.4664 & 2.161633 & 4.776374 & $04-19$ & $10-09$ & 174 & 18 \\
2005 & 134 & 2522 & 0.791295 & 15.11767 & 3.763013 & 20.07063 & $05-03$ & $10-15$ & 166 & 34 \\
2006 & 42 & 1882 & 0.4145852 & 7.92064 & 1.919028 & 3.724251 & $04-11$ & $10-10$ & 183 & 8 \\
2007 & 46 & 2271 & 0.516512 & 9.86795 & 1.863802 & 3.176721 & $04-04$ & $09-24$ & 174 & 15 \\
2008 & 88 & 2788 & 0.7529173 & 14.38446 & 2.52917 & 6.923497 & $04-01$ & $09-30$ & 183 & 30 \\
2009 & 111 & 2684 & 0.719136 & 13.73907 & 3.015093 & 13.06133 & $04-30$ & $10-08$ & 162 & 29 \\
\hline
\end{tabular}

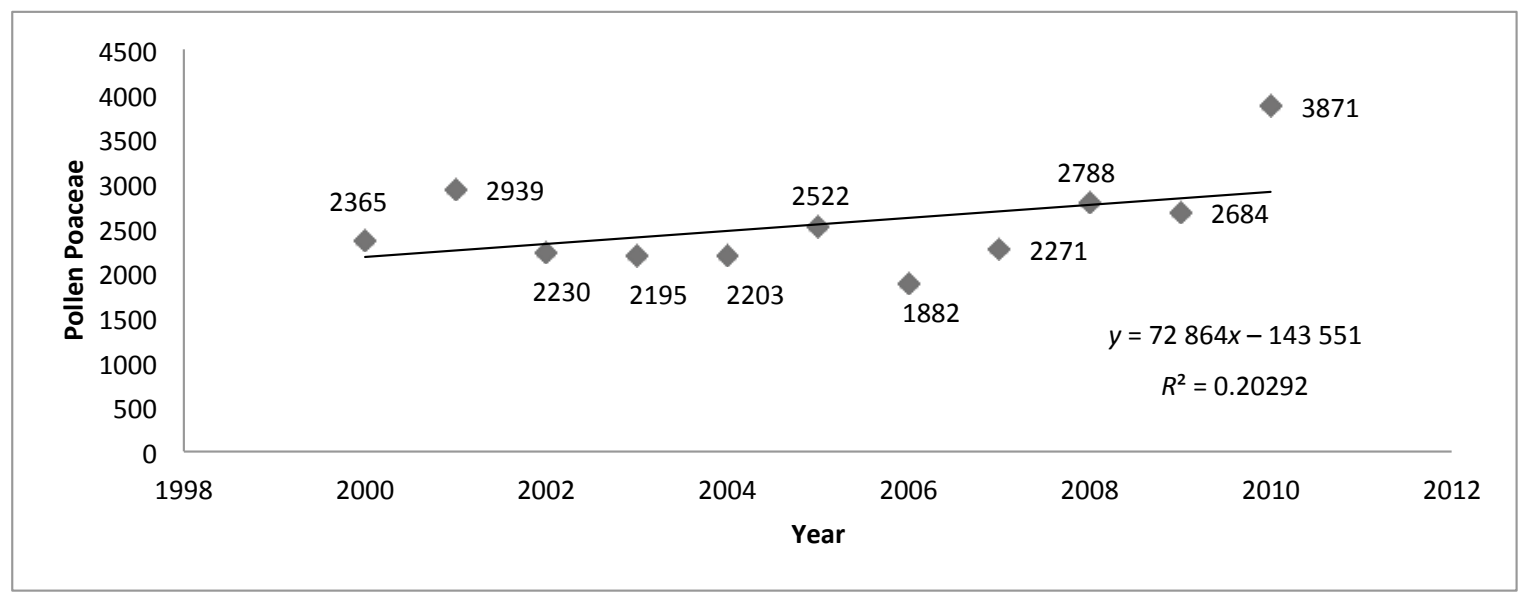

Fig. 1 Annual fluctuations in Poaceae airborne pollen.

May). The distributions of Poaceae pollen concentrations in the individual seasons were asymmetric (right-skewed distribution), which means a long-lasting presence of airborne pollen, with extreme values to the right. For almost all years, the Poaceae pollen concentrations have high values of kurtosis point (leptokurtic distribution). May and June were the months with the highest daily Poaceae pollen concentrations during the study period. Poaceae anthesis was prolonged till the beginning of October, along with that of plants belonging to genera such as Ambrosia, Artemisia and Chenopodiaceae/Amaranthaceae. An increasing trend in the annual totals is observed $\left(R^{2}=0.2029\right.$; Fig. 1$)$.

Spearman's test was employed to determine the degree of correlation between pollen concentration and meteorological conditions and the 11-year data were analyzed. Over the period 2000-2010, we found the same pattern of Poaceae pollen (Tab. 2). Mean daily average temperature, minimum temperature and maximum temperature were positively associated with concentration of airborne Poaceae pollen. The total daily hours of sunshine showed positive and significant correlations in these years. Spearman's rank correlation analysis also revealed a negative and significant influence of relative air humidity on airborne pollen. Increased pressure impacted on the decrease in concentrations of Poaceae pollen in the atmosphere. Weak negative correlations were observed in the case of precipitation. In addition, the correlation between Poaceae pollen concentrations and wind speed was not statistically significant (except in 2007).

The multiple regression analysis was performed to determine how much of the total variance in atmospheric Poaceae pollen counts can be explained by meteorological variables (independent, predictor, explanatory or regressor variables). We analyzed the effect of meteorological factors on pollen concentrations taking the season as a whole, over a full 
Tab. 2 Coefficients of correlation between Poaceae pollen concentrations and the main meteorological parameters by using the Spearman correlation test.

\begin{tabular}{|c|c|c|c|c|c|c|c|c|c|}
\hline Year & $\begin{array}{l}\text { Mean daily } \\
\text { average } \\
\text { temperature } \\
\left({ }^{\circ} \mathrm{C}\right)\end{array}$ & $\begin{array}{c}\text { Maximum } \\
\text { temperature } \\
\left({ }^{\circ} \mathrm{C}\right)\end{array}$ & $\begin{array}{c}\text { Minimum } \\
\text { temperature } \\
\left({ }^{\circ} \mathrm{C}\right)\end{array}$ & $\begin{array}{c}\text { Quantities of } \\
\text { precipitation } \\
\left(\mathbf{L} / \mathbf{m}^{2}\right)\end{array}$ & $\begin{array}{l}\text { Daily average } \\
\text { relative } \\
\text { humidity }(\%)\end{array}$ & $\begin{array}{l}\text { Sunshine } \\
\text { hours (h) }\end{array}$ & $\begin{array}{c}\text { Atmospheric } \\
\text { pressure } \\
\text { (millibars) }\end{array}$ & $\begin{array}{c}\text { Daily } \\
\text { average wind } \\
\text { speed }(\mathrm{m} / \mathrm{s})\end{array}$ & $\begin{array}{c}\text { Daily max. } \\
\text { wind speed } \\
(\mathrm{m} / \mathrm{s})\end{array}$ \\
\hline 2000 & $0.829^{* *}$ & $0.813^{* *}$ & $0.802^{* *}$ & $-0.138^{* *}$ & $-0.636^{* *}$ & $0.585^{* *}$ & $-0.243^{* *}$ & 0.062 & 0.071 \\
\hline 2001 & $0.797^{* *}$ & $0.777^{* *}$ & $0.739^{* *}$ & -0.004 & $-0.461^{* *}$ & $0.531^{* *}$ & $-0.192^{* *}$ & 0.090 & 0.026 \\
\hline 2002 & $0.701^{* *}$ & $0.691^{* *}$ & $0.681^{* *}$ & -0.020 & $-0.297^{* *}$ & $0.424^{* *}$ & $-0.241^{* *}$ & -0.017 & 0.028 \\
\hline 2003 & $0.823^{* *}$ & $0.813^{* *}$ & $0.796^{* *}$ & -0.065 & $-0.582^{* *}$ & $0.607^{* *}$ & $-0.253^{* *}$ & 0.055 & 0.040 \\
\hline 2004 & $0.781^{* *}$ & $0.754^{* *}$ & $0.719^{* *}$ & $-0.176^{* *}$ & $-0.571^{* *}$ & $0.608^{* *}$ & $-0.149^{* *}$ & 0.069 & 0.062 \\
\hline 2005 & $0.792^{* *}$ & $0.771^{* *}$ & $0.761^{* *}$ & $-0.142^{* *}$ & $-0.439^{* *}$ & $0.481^{* *}$ & $-0.148^{* *}$ & 0.075 & 0.029 \\
\hline 2006 & $0.800^{* *}$ & $0.763^{* *}$ & $0.781^{* *}$ & 0.012 & $-0.503^{* *}$ & $0.507^{* *}$ & $-0.178^{* *}$ & 0.092 & 0.017 \\
\hline 2007 & $0.796^{* *}$ & $0.780^{* *}$ & $0.743^{* *}$ & 0.007 & $-0.557^{* *}$ & $0.537^{* *}$ & $-0.396^{* *}$ & $0.110^{*}$ & 0.063 \\
\hline 2008 & $0.805^{* *}$ & $0.762^{* *}$ & $0.781^{* *}$ & -0.054 & $-0.485^{* *}$ & $0.525^{* *}$ & $-0.332^{* *}$ & 0.024 & -0.050 \\
\hline 2009 & $0.767^{* *}$ & $0.760^{* *}$ & $0.734^{* *}$ & $-0.120^{*}$ & $-0.380^{* *}$ & $0.504^{* *}$ & 0.030 & -0.046 & -0.068 \\
\hline 2010 & $0.795^{* *}$ & $0.763^{* *}$ & $0.782^{* *}$ & 0.000035 & $-0.398^{* *}$ & $0.438^{* *}$ & $-0.119^{*}$ & -0.020 & -0.023 \\
\hline
\end{tabular}

** Correlation is significant at the 0.01 level. * Correlation is significant at the 0.05 level.

year. In this way, we included the data from all phenological stages of plants. The coefficient of determination $\left(R^{2}\right)$ of the multiple regressions varied from 0.245 to 0.460 (Tab. 3). A very low value of the coefficient of determination was found only in 2002. The values of the multiple correlation coefficient indicate a good level of prediction. Statistically significantly meteorological factors (different to 0 ) differed between the years of study (Tab. 4). Unstandardized coefficients indicate how much the pollen concentration (dependent variable) varies with an independent variable when all other independent variables are held constant. This means that for each one degree increase in mean daily average temperature, there is an increase in pollen concentrations. On the other hand, for each one degree increase in maximum temperature and minimum temperature, there is a decrease in pollen concentrations on the same day. Low and high temperatures have a limiting effect on the presence of pollen grains in the air. The most important factors influencing the Poaceae pollen count are mean daily average temperature, maximum temperature, minimum temperature, and sunshine hours.

\section{Discussion}

Seasonal dynamics of pollen grains are better analyzed using meteorological parameters because the normal development of flowering in plant species is influenced by the climatic conditions in which this flowering occurs. If the conditions are adverse, the plant species have phenological and physiological strategies to survive but pollen

Tab. 3 Multiple regression variable result (model summary and ANOVA table).

\begin{tabular}{|c|c|c|c|c|c|c|}
\hline Year & $\begin{array}{c}\text { Multiple } \\
\text { correlation } \\
\text { coefficient }(R)\end{array}$ & $\begin{array}{c}\text { Coefficient of } \\
\text { determination } \\
\text { ( } R \text { square, } R^{2} \\
\text { value) }\end{array}$ & $\begin{array}{l}\text { Adjusted } R \\
\text { square }\end{array}$ & $\begin{array}{l}\text { Std. error of the } \\
\text { estimate }\end{array}$ & ANOVA F-ratio & $\begin{array}{c}\text { Regression } \\
\text { variable result } \\
\text { - proportion of } \\
\text { variance explained }\end{array}$ \\
\hline 2000 & 0.665 & 0.443 & 0.429 & 7.03475 & 31.350 & $44.3 \%$ \\
\hline 2001 & 0.659 & 0.435 & 0.421 & 9.62605 & 30.356 & $43.5 \%$ \\
\hline 2002 & 0.495 & 0.245 & 0.226 & 10.12412 & 12.821 & $24.5 \%$ \\
\hline 2003 & 0.678 & 0.460 & 0.447 & 7.15644 & 33.649 & $46.0 \%$ \\
\hline 2004 & 0.652 & 0.425 & 0.411 & 8.03484 & 29.183 & $42.5 \%$ \\
\hline 2005 & 0.560 & 0.314 & 0.296 & 12.68135 & 18.033 & $31.4 \%$ \\
\hline 2006 & 0.662 & 0.438 & 0.424 & 6.01362 & 30.718 & $43.8 \%$ \\
\hline 2007 & 0.621 & 0.385 & 0.370 & 7.83505 & 24.710 & $38.5 \%$ \\
\hline 2008 & 0.605 & 0.366 & 0.349 & 11.60161 & 22.730 & $36.6 \%$ \\
\hline 2009 & 0.520 & 0.270 & 0.252 & 11.88597 & 14.594 & $27.0 \%$ \\
\hline 2010 & 0.549 & 0.301 & 0.284 & 18.21790 & 17.014 & $30.1 \%$ \\
\hline
\end{tabular}


Tab. 4 The significant factors in multiple regression analysis for Poaceae pollen.

\begin{tabular}{|c|c|c|c|c|}
\hline \multirow[b]{2}{*}{ Year } & \multirow[b]{2}{*}{ Explanatory variables } & \multicolumn{2}{|c|}{ Unstandardized coefficients } & \multirow[b]{2}{*}{$P$-value (Sig.) } \\
\hline & & B & Std. error & \\
\hline \multirow[t]{5}{*}{2000} & mean daily average temperature $\left({ }^{\circ} \mathrm{C}\right)$ & 1.603 & 0.473 & 0.000777 \\
\hline & maximum temperature $\left({ }^{\circ} \mathrm{C}\right)$ & -0.520 & 0.234 & 0.027013 \\
\hline & sunshine hours (h) & 0.291 & 0.146 & 0.046246 \\
\hline & daily average relative humidity (\%) & 0.127 & 0.056 & 0.023551 \\
\hline & atmospheric pressure (millibars) & 0.150 & 0.069 & 0.029796 \\
\hline \multirow[t]{7}{*}{2001} & mean daily average temperature $\left({ }^{\circ} \mathrm{C}\right)$ & 3.071 & 0.637 & 0.000002 \\
\hline & maximum temperature $\left({ }^{\circ} \mathrm{C}\right)$ & -0.939 & 0.322 & 0.003758 \\
\hline & minimum temperature $\left({ }^{\circ} \mathrm{C}\right)$ & -1.533 & 0.405 & 0.000177 \\
\hline & quantities of precipitations $\left(1 / \mathrm{m}^{2}\right)$ & 0.439 & 0.129 & 0.000740 \\
\hline & daily average relative humidity (\%) & -0.175 & 0.075 & 0.020137 \\
\hline & daily average wind speed $(\mathrm{m} / \mathrm{s})$ & 2.395 & 1.171 & 0.041475 \\
\hline & daily max. wind speed $(\mathrm{m} / \mathrm{s})$ & -1.893 & 0.761 & 0.013365 \\
\hline 2002 & - & & & \\
\hline \multirow[t]{4}{*}{2003} & mean daily average temperature $\left({ }^{\circ} \mathrm{C}\right)$ & 1.951 & 0.475 & 0.000050 \\
\hline & maximum temperature $\left({ }^{\circ} \mathrm{C}\right)$ & -0.703 & 0.262 & 0.007607 \\
\hline & minimum temperature $\left({ }^{\circ} \mathrm{C}\right)$ & -0.725 & 0.292 & 0.013317 \\
\hline & sunshine hours (h) & 0.394 & 0.150 & 0.008972 \\
\hline \multirow[t]{7}{*}{2004} & mean daily average temperature $\left({ }^{\circ} \mathrm{C}\right)$ & 2.515 & 0.552 & 0.000007 \\
\hline & maximum temperature $\left({ }^{\circ} \mathrm{C}\right)$ & -1.302 & 0.284 & 0.000006 \\
\hline & minimum temperature $\left({ }^{\circ} \mathrm{C}\right)$ & -0.769 & 0.347 & 0.027193 \\
\hline & daily average relative humidity (\%) & -0.146 & 0.067 & 0.030109 \\
\hline & sunshine hours (h) & 0.646 & 0.176 & 0.000286 \\
\hline & daily average wind speed $(\mathrm{m} / \mathrm{s})$ & 2.343 & 1.007 & 0.020527 \\
\hline & daily max. wind speed $(\mathrm{m} / \mathrm{s})$ & -1.861 & 0.696 & 0.007812 \\
\hline \multirow[t]{4}{*}{2005} & mean daily average temperature $\left({ }^{\circ} \mathrm{C}\right)$ & 3.516 & 0.884 & 0.000084 \\
\hline & maximum temperature $\left({ }^{\circ} \mathrm{C}\right)$ & -1.443 & 0.446 & 0.001337 \\
\hline & minimum temperature $\left({ }^{\circ} \mathrm{C}\right)$ & -1.426 & 0.582 & 0.014771 \\
\hline & sunshine hours (h) & 0.569 & 0.282 & 0.044628 \\
\hline \multirow[t]{6}{*}{2006} & mean daily average temperature $\left({ }^{\circ} \mathrm{C}\right)$ & 1.631 & 0.439 & 0.000237 \\
\hline & maximum temperature $\left({ }^{\circ} \mathrm{C}\right)$ & -0.856 & 0.221 & 0.000124 \\
\hline & quantities of precipitations $\left(1 / \mathrm{m}^{2}\right)$ & 0.186 & 0.094 & 0.047864 \\
\hline & sunshine hours (h) & 0.526 & 0.151 & 0.000539 \\
\hline & atmospheric pressure (millibars) & 0.143 & 0.054 & 0.008786 \\
\hline & daily average wind speed $(\mathrm{m} / \mathrm{s})$ & 1.995 & 0.870 & 0.022499 \\
\hline \multirow[t]{3}{*}{2007} & mean daily average temperature $\left({ }^{\circ} \mathrm{C}\right)$ & 2.197 & 0.581 & 0.000184 \\
\hline & maximum temperature $\left({ }^{\circ} \mathrm{C}\right)$ & -0.954 & 0.307 & 0.002044 \\
\hline & sunshine hours (h) & 0.483 & 0.217 & 0.026200 \\
\hline \multirow[t]{6}{*}{2008} & mean daily average temperature $\left({ }^{\circ} \mathrm{C}\right)$ & 4.096 & 0.786 & 0.0000003 \\
\hline & maximum temperature $\left({ }^{\circ} \mathrm{C}\right)$ & -1.792 & 0.408 & 0.0000148 \\
\hline & minimum temperature $\left({ }^{\circ} \mathrm{C}\right)$ & -1.260 & 0.511 & 0.0142329 \\
\hline & quantities of precipitations $\left(1 / \mathrm{m}^{2}\right)$ & 0.315 & 0.146 & 0.0310229 \\
\hline & daily average relative humidity (\%) & 0.274 & 0.099 & 0.0060331 \\
\hline & sunshine hours (h) & 0.775 & 0.317 & 0.0151653 \\
\hline \multirow[t]{2}{*}{2009} & mean daily average temperature $\left({ }^{\circ} \mathrm{C}\right)$ & 1.551 & 0.765 & 0.043368 \\
\hline & daily average relative humidity (\%) & 0.145 & 0.073 & 0.049288 \\
\hline \multirow[t]{4}{*}{2010} & mean daily average temperature $\left({ }^{\circ} \mathrm{C}\right)$ & 4.149 & 1.298 & 0.001517 \\
\hline & maximum temperature $\left({ }^{\circ} \mathrm{C}\right)$ & -2.346 & 0.650 & 0.000349 \\
\hline & daily average relative humidity (\%) & 0.467 & 0.171 & 0.006643 \\
\hline & sunshine hours (h) & 2.030 & 0.498 & 0.000057 \\
\hline
\end{tabular}


production may be reduced. Variables which have been described in the literature with statistical significance also have a significant correlation in our study. Similar to other European countries, the most important parameters affecting the variation in daily Poaceae pollen concentrations are temperature, sunshine (positive correlation), and average relative humidity (negative correlation) [31]. Sánchez-Mesa et al. [32] have shown that minimum temperature was the most important factor in the city of Cordoba. In London, the most important factor was maximum temperature [33]. Other several studies found significant positive correlations between daily Poaceae pollen concentration and daily maximum temperature $[31,34]$, daily mean temperature $[35,36]$, and daily global solar flux [31,34]. Relative humidity and rainfall [35-40] had a negative effect. Many studies indicate some meteorological elements related to the start of Poaceae seasons: mean temperature in March-April (in the Netherlands), mean temperature before the season start (in Poland), total rainfall in July (in Australia), rainfall in June (in the Iberian Peninsula), cumulative temperature above $5.5^{\circ} \mathrm{C}$ in March-April, minimum temperature in the first decade of April and maximum temperature in the second decade of April (in the United Kingdom) [41-46]. Daily maximum temperature (optimum $21-25^{\circ} \mathrm{C}$ ), daily mean temperature and anticyclonic synoptic situation on the day before the forecasted day have been reported as the main variables influencing the daily Poaceae pollen concentration $[8,29,39,47,48]$.

The interpretations of most reports are based on various methods of statistical analysis (Pearson or Spearman correlation, regression analysis, time series analysis, artificial neural networks) [49]. The results of analysis in different areas are not always comparable because of different methods defining the pollen season characteristics and specific weather conditions. In our opinion, regression analysis reveals more nuanced effects of meteorological factors than the Spearman correlation. On the one hand, the mean daily average temperatures showed a significant positive strong relation with Poaceae pollen type, which reveals the importance of this meteorological parameter in flowering and pollen production. The same can be said for sunshine, a meteorological variable that induces anther dehiscence and filament extension. On the other hand, the multiple regression analysis highlights the contrasting effects of respectively minimum and maximum average temperatures on the concentration of pollen in the air. There are also contrasting effects of wind speed. In fact, wind speed plays an ambivalent role, partly having a positive impact by increasing pollen shed from the anthers (daily average wind speed), partly a negative relationship by diluting pollen from the air (daily maximum wind speed) $[24,34]$. Poaceae plants produce high amounts of pollen, while the winds, a vector of pollination, reduce its efficiency. In addition, it is interesting to note the positive influence of the increase in daily average relative humidity and quantities of precipitation in some years. Even if some species are able to adjust their vegetative and reproductive cycles to availability of water, most of them react negatively, keeping the reproductive functions at the minimum compatible with life. Increased water availability for plants results in increased pollen release into the air. Similarly, extreme temperatures are also the cause of responses deviated from the optimum for plant species. Warm stress and cold stress are factors that affect microsporogenesis and pollen production [50].

Generally, the Poaceae tend to start growing in the early spring. In the late spring and early summer, Poaceae species release pollen into the air. In all years, a distinctive decrease in the pollen amount started in the first half of September. The pollen season in Timisoara lasts for about 5 months. The Poaceae pollen count is recorded from the second half of April until the first half of October. The pollination season is long because of a great number of Poaceae species. The presence of airborne pollen is related to the timing of flowering of plants [51]. The pollen season of Poaceae in Northern, Central and Eastern Europe lasts from the beginning of May to the end of July, while in Southern Europe - from April to June [18]. Similar season characteristics were observed in Szczecin, Poznań, Lublin, Szeged, Novi Sad and Zagreb [16,36,38,52].

A growing trend with minor changes in the abundance of pollen in successive seasons was observed for Poaceae in Italy [53], Sweden [54] and Switzerland [55]. In the longterm observations conducted in Denmark, the Netherlands, Belgium and Great Britain, no distinct trends have been established [42].

In cities, pollen sources are limited. The structure of buildings and intricate surfaces within cities diminish pollen dispersal. In cities, there occurs a microclimatic change in temperature known as an urban heat island which causes different pollen concentrations over short distances, both vertically and horizontally. It can also influence plant phenology and induce a breeze system, which can bring pollen from large distances [56,57]. The increase in the years 2007-2010 is likely to be related to the changes in agricultural activities, an increasing number of farms and increased land use, such as the use as pastures [58], the expanding metropolitan area, and the construction of new buildings.

The greatest risk from Poaceae for pollen allergy sufferers in Timisoara (days $>30$ grains $/ \mathrm{m}^{3}$ ) lasts on average from mid-May to mid-July. Estimations indicate that in Europe $3-5 \%$ of the population suffer from pollinosis during the flowering season of Poaceae. If someone is allergic, his or her body may react even to a small amount of pollen grains. The concentration of airborne Poaceae pollen influences the degree of symptoms in pollinosis patients [18]. In London (UK), the lowest atmospheric concentration of grass pollen able to induce the appearance of symptoms was shown to be $10-50 \mathrm{APG} / \mathrm{m}^{3}$ [59]. In Cardiff (UK), $10 \%$ of pollinosis patients experienced symptoms in the presence of 10 APG/ $\mathrm{m}^{3}$. In Turku (Finland), a count of less than $30 \mathrm{APG} / \mathrm{m}^{3}$ was significantly correlated with nasal symptoms at the start of the Poaceae-pollen season [60]. In Poland, people sensitive to Poaceae pollen developed the first disease symptoms when exposed to more than $20 \mathrm{APG} / \mathrm{m}^{3}$ [61]. In Croatia, Hungary and Serbia, the threshold value amounts to 30 APG/ $\mathrm{m}^{3}[16,36]$, whereas in Spain the first allergy symptoms were observed at $25 \mathrm{APG} / \mathrm{m}^{3}$ [62]. For children and adolescents from Malmö (Sweden), nose symptom scores increased continuously and linearly with pollen counts from concentrations of $0-30 \mathrm{APG} / \mathrm{m}^{3}$, wherefrom symptom severity 
increased faster until about $80 \mathrm{APG} / \mathrm{m}^{3}$. Eye symptom scores increased with pollen count beyond concentrations of about $70 \mathrm{APG} / \mathrm{m}^{3}$ and did not level out until about 140-150 APG/ $\mathrm{m}^{3}$. There was no apparent change in symptom severity until levels above $50 \mathrm{APG} / \mathrm{m}^{3}$ in case of lung symptoms scores. From levels above about $70 \mathrm{APG} / \mathrm{m}^{3}$, the increase appeared almost linear [63]. Erbas et al. [64] demonstrated that a concentration of $30 \mathrm{APG} / \mathrm{m}^{3}$ was sufficient to induce symptoms in most grass-allergic asthmatics in Melbourne, Australia. De Weger et al. [65] found that Poaceae pollen allergic patients have more severe symptoms in the early season compared to the late season at similar concentrations.

Some studies highlight the fact that the threshold concentrations at which symptoms of allergy to grass pollen are observed are influenced by the degree of air pollution. In areas of high air pollution, the allergy threshold pollen value is $30 \mathrm{APG} / \mathrm{m}^{3}$, while in areas of low air pollution it is $71 \mathrm{APG} / \mathrm{m}^{3}$ [60]. In big and highly industrialized cities, grass pollens are the major allergens, while in other areas they are the minor allergens. The difference can be attributed to the chemical properties of allergens and the presence of substances facilitating allergy-inducing properties in the air, such as ozone, sulfur oxides, nitrogen oxides, and dusts [52]. Some estimated effects of climate change are increasing

\section{Acknowledgments}

The study was financed by a Romanian national grant, Program 4 Partnership (PN2-41-011/2007-2013, PREVALERG) - Minister of Education, Research, Youth and Sports.

\section{Competing interests}

No competing interests have been declared.

\section{References}

1. Watson L, Dallwitz MJ. The grass genera of the world. Wallingford: CAB International; 1992.

2. Osborne CP, Freckleton RP. Ecological selection pressures for $\mathrm{C} 4$ photosynthesis in the grasses. Proc Biol Sci. 2009;276:1753-1760. http://dx.doi.org/10.1098/rspb.2008.1762

3. Stanley KE. Evolutionary trends in the grasses (Poaceae): a review. Michigan Bot. 1999;38(1):3-12.

4. Damialis A, Konstantinou GN. Cereal pollen sensitisation in pollen allergic patients: to treat or not to treat? Eur Ann Allergy Clin Immunol. 2011;43(2):36-44.

5. Ianovici N, Jurca A, Faur A. Poaceae pollen analysis in SW of Romania. In: Proceeding of VIth International Symposium "Young people and multidisciplinary research"; 2004 Sep 23-24; Timișoara, Romania. Timişoara: Editura Sudura; p. 416-425.

6. Byrt CS, Grof CPL, Furbank RT. C4 plants as biofuel feedstocks: optimising biomass production and feedstock quality from a lignocellulosic perspective. J Integr Plant Biol. 2011;53:120-135. http://dx.doi. org/10.1111/j.1744-7909.2010.01023.x

7. Malkiewicz M, Klaczak K. Analysis of the grass (Poaceae L.) pollen seasons in Wrocław, 2003-2010. Acta Agrobot. 2011;64(4):59-66. http://dx.doi.org/10.5586/aa.2011.046

8. Aboulaich N, Bouziane H, Kadiri M, del Mar Trigo M, Riadi H, Kazzaz $\mathrm{M}$, et al. Pollen production in anemophilous species of the Poaceae family in Tetouan (NW Morocco). Aerobiologia. 2009;25:27-38. http://dx.doi.org/10.1007/s10453-008-9106-2

9. Andersson K, Lindholm J. Characteristic and immunobiology of grass pollen allergens. Int Arch Allergy Immunol. 2003;130:87-107. http:// dx.doi.org/10.1159/000069013 allergic symptoms through changes in pollen biology, modifying the patterns of emission and transport of allergenic pollen [66]. Using quantitative estimates of increased pollen production and number of flowering plants per treatment, Albertine et al. [67] estimated that airborne grass pollen concentrations will increase in the future up to $200 \%$. In some works, it is reported that pollen release increases with increasing temperature, which is based on the greenhouse effect due to increasing $\mathrm{CO}_{2}$ emission [67].

\section{Conclusions}

In Timisoara, the length of the seasons and the cumulative counts varied over the eleven years. The time of maximum counts for Poaceae pollen occurs between mid-May to mid-July. The pollen release, transportation and dispersal are closely linked with meteorological parameters. In all years, the Poaceae pollen concentration showed a statistically significant correlation with temperature and sunshine. The statistical method used is relevant in interpreting the data of pollen concentrations. The effects of meteorological factors seem to have contrasting effects on the Poaceae pollen concentration when employing multiple regression.

10. Beggs PJ, Katelaris CH, Medek D, Johnston FH, Burton PK, Campbell $\mathrm{B}$, et al. Differences in grass pollen allergen exposure across Australia. Aust N Z J Public Health. 2015;39:51-55. http://dx.doi. org/10.1111/1753-6405.12325

11. Asero R, Mistrello G, Roncarolo D, D’Amato G, Zanoni D, Barocci $F$, et al. Detection of clinical markers of sensitisation to profilin in patients allergic to plant-derived foods. J Allergy Clin Immunol. 2003;112:417-423. http://dx.doi.org/10.1067/mai.2003.1611

12. Ree R, Voitenko V, Leeuwen WA, Aalberse RC. Profilin is a crossreactive allergen in pollen and vegetables food. Int Arch Allergy Immunol. 1992;98:97-104. http://dx.doi.org/10.1159/000236171

13. Taketomi EA, Sopelete MC, de Sousa Moreira PF, de Assis Machado Vieira F. Pollen allergic disease: pollens and its major allergens. Braz J Otorhinolaryngol. 2006;72(4):562-567. http://dx.doi.org/10.1016/ S1808-8694(15)31005-3

14. Wüthrich B, Schindler C, Leuenberger P, Ackermann-Liebrich P. Prevalence of atopy and pollinosis in the adult population of Switzerland (SAPALDIA study). Int Arch Allergy Immunol. 1995;106(2):149-156. http://dx.doi.org/10.1159/000236836

15. Nowak D, Heinrich J, Jorres R, Wassmer G, Berger J, Beck E, et al. Prevalence of respiratory symptoms, bronchial hyperresponsiveness and atopy among adults: west and east Germany. Eur Respir J. 1996;9:2541-2552. http://dx.doi.org/10.1183/09031936.96.09122541

16. Juhász IE, Juhász M, Radišič P, Ianovici N, Sikoparija B. Aerobiological importance of grasses in the DKMT Euroregion. In: The 12th Symposium on Analytical and Environmental Problems; 2005 Sep 26; Szeged, Hungary. Szeged: Zoltán Galbács, SZAB Kémiai Szakbizottság Analitikai és Környezetvédelmi Munkabizottsága. p. 144-148.

17. Gioulekas D, Papakosta D, Damialis A, Spieksma F, Giouleka P, Patakas D. Allergenic pollen records (15 years) and sensitisation in patients with respiratory allergy in Thessaloniki, Greece. Allergy. 2004;59:174-184. http://dx.doi.org/10.1046/j.1398-9995.2003.00312.x

18. D’Amato G, Cecchi L, Bonini S, Nunes C, Annesi-Maesano I, Behrendt $\mathrm{H}$, et al. Allergenic pollen and pollen allergy in Europe. Allergy. 2007;62:976-990. http://dx.doi.org/10.1111/j.1398-9995.2007.01393.x

19. Erbas B, Akram M, Dharmage SC, Tham R, Dennekamp M, Newbigin $\mathrm{E}$, et al. The role of seasonal grass pollen on childhood asthma 
emergency department presentations. Clin Exp Allergy. 2012;42:799_ 805. http://dx.doi.org/10.1111/j.1365-2222.2012.03995.x

20. Ianovici N, Panaitescu Bunu C, Brudiu I. Analysis of airborne allergenic pollen spectrum for 2009 in Timisoara, Romania. Aerobiologia. 2013;29(1):95-111. http://dx.doi.org/10.1007/s10453-012-9266-y

21. Faur A, Ianovici N. Biologic pollution with grasses's in the south-west of Romania. Annals of West University of Timisoara, ser. Biology. 2001;3-4:1-6.

22. Ianovici N. The principal airborne and allergenic pollen species in Timisoara. Annals of West University of Timisoara, ser. Biology. 2007;10:11-26.

23. Faur A, Ianovici N, Nechifor C. Airpalynology research implications in allergic diseases. Annals of West University of Timisoara, ser. Biology. 2001;3-4:7-14.

24. Ianovici N. Airborne Poaceae pollen in urban environment for 2000-2004. Analele Universitatii din Craiova - Agricultură, Montanologie, Cadastru. 2008;38(B):224-230

25. Leru PM, Matei D, Ianovici N. Health impact of Ambrosia artemisiifolia reflected by allergists practice in Romania. A questionnairebased survey. Annals of West University of Timisoara, ser. Biology. 2015;18(1):43-54.

26. Ianovici N, Maria C, Răduțoiu MN, Haniș A, Tudorică D. Variation in airborne fungal spore concentrations in four different microclimate regions in Romania. Not Bot Horti Agrobot Cluj Napoca. 2013;41(2):450-457.

27. Myszkowska D. Poaceae pollen in the air depending on the thermal conditions. Int J Biometeorol. 2014;58:975-986. http://dx.doi. org/10.1007/s00484-013-0682-7

28. Puc M, Wolski T. Forecasting of the selected features of Poaceae (R. Br.) Barnh., Artemisia L. and Ambrosia L. pollen season in Szczecin (northwestern Poland) using Gumbel's distribution. Ann Agric Environ Med. 2013;20(1):36-47.

29. Matyasovszky I, Makra L, Guba Z, Pátkai Z, Páldy A, Sümeghy Z. Estimating the daily Poaceae pollen concentration in Hungary by linear regression conditioning on weather types. Grana. 2011;50:208-216. http://dx.doi.org/10.1080/00173134.2011.602984

30. Zhang R, Duhl T, Salam MT, House JM, Flagan RC, Avol EL, et al. Development of a regional-scale pollen emission and transport modeling framework for investigating the impact of climate change on allergic airway disease. Biogeosciences. 2014;11:1461-1478. http:// dx.doi.org/10.5194/bg-11-1461-2014

31. Kasprzyk I, Walanus A. Description of the main Poaceae pollen season using bi-Gaussian curves, and forecasting methods for the start and peak dates for this type of season in Rzeszow and Ostrowiec Sw. (SE Poland). J Environ Monit. 2010;12:906-916. http://dx.doi. org/10.1039/b912256g

32. Sánchez-Mesa JA, Galán C, Hervás-Martinez C. The use of discriminant analysis and neural network to forecast the severity of the Poaceae pollen season in a region with a typical Mediterranean climate. Int J Biometeorol. 2005;49:355-362. http://dx.doi.org/10.1007/ s00484-005-0260-8

33. Galán C, Emberlin J, Dominguez E, Bryant RH, Villamandos F. A comparative analysis of daily variations in the Gramineae pollen counts at Còrdoba, Spain and London, UK. Grana. 1995;34:189-198. http://dx.doi.org/10.1080/00173139509429042

34. Valencia-Barrera RM, Comtois P, Fernández-González D. Biogeography and bioclimatology in pollen forecasting - an example of grass in León (Spain) and Montreal (Canada). Grana. 2001;40:223-229. http://dx.doi.org/10.1080/001731301317223259

35. Puc M, Puc MI. Allergenic airborne grass pollen in Szczecin, Poland. Ann Agric Environ Med. 2004;11:237-244.

36. Peternel R, Srnec L, Culig J, Hrga I, Hercog P. Poaceae pollen in the atmosphere of Zagreb (Croatia), 2002-2005. Grana. 2006;45:130-136. http://dx.doi.org/10.1080/00173130600662114

37. Bartkovă-Ščevkovă J. The influence of temperature, relative humidity and rainfall on the occurrence of pollen allergens (Betula, Poaceae, Ambrosia artemisifolia) in the atmosphere in Bratislava
(Slovakia). Int J Biometeorol. 2003;48:1-5. http://dx.doi.org/10.1007/ s00484-003-0166-2

38. Piotrowska K, Weryszko-Chmielewska E. Pollen count of selected taxa in the atmosphere of Lublin using two monitoring methods. Ann Agric Environ Med. 2003;10:79-85.

39. Green BJ, Dettmann M, Yli-Panula E, Rutherford S, Simpson R. Atmospheric Poaceae pollen frequencies and associations with meteorological parameters in Brisbane, Australia: a 5-year record, 1994-1999. Int J Biometeorol. 2004;48:172-178. http://dx.doi. org/10.1007/s00484-004-0204-8

40. Docampo S, Recio M, Mar Trigo M, Melgar M, Cabezudo B. Risk of allergy in Nerja (southern Spain): a pollen calendar. Aerobiologia. 2007;23:189-199. http://dx.doi.org/10.1007/s10453-007-9063-1

41. Emberlin J, Savage M, Jones S. Annual variations in grass pollen seasons in London 1961-1990: trends and forecast models. Clin Exp Allergy. 1993;23:911-918. http://dx.doi.org/10.1111/j.1365-2222.1993. tb00275.x

42. Spieksma FTM, Nikkels H. Airborne grass pollen in Leiden, the Netherlands: annual variations and trends in quantities and season starts over 26 years. Aerobiologia. 1998;14:347-358. http://dx.doi. org/10.1007/BF02694304

43. Stach A, Smith M, Prieto Buena JC, Emberlin J. Long-term and short-term forecast models for Poaceae (grass) pollen in Poznań, Poland, constructed using regression analysis. Environ Exp Botany. 2008;62:323-332. http://dx.doi.org/10.1016/j.envexpbot.2007.10.005

44. Ong EK, Taylor PE, Knox RB. Forecasting the onset of the grass pollen season in Melbourne (Australia). Aerobiologia. 1997;13:43-48. http:// dx.doi.org/10.1007/BF02694790

45. Smith M, Emberlin J. Constructing a 7-day ahead forecast model for grass pollen at north London, United Kingdom. Clin Exp Allergy. 2005;35:1400-1406. http://dx.doi. org/10.1111/j.1365-2222.2005.02349.x

46. Cariñanos P, Galán C, Alcázar P, Domingues-Vilches E. Airborne pollen records response to climatic conditions in arid areas of the Iberian Peninsula. Environ Exp Bot. 2004;52:11-22. http://dx.doi. org/10.1016/j.envexpbot.2003.11.008

47. Norris-Hill J. The influence of ambient temperature on the abundance of Poaceae pollen. Aerobiologia. 1997;13:91-97. http://dx.doi. org/10.1007/BF02694424

48. Schäppi GF, Taylor PE, Kenrick J, Staff IA, Suphioglu C. Predicting the grass pollen count from meteorological data with regard to estimating the severity of hayfever symptoms in Melbourne (Australia). Aerobiologia. 1998;14:29-37. http://dx.doi.org/10.1007/BF02694592

49. Myszkowska D, Majewska R. Pollen grains as allergenic environmental factors - new approach to the forecasting of the pollen concentration during the season. Ann Agric Environ Med. 2014;21(4):681-688. http://dx.doi.org/10.5604/12321966.1129914

50. Ianovici N. Seasonal variations in the atmospheric Chenopodiaceae/ Amaranthaceae pollen count in Timisoara, Romania. Not Bot Horti Agrobot Cluj Napoca. 2008;36(2):17-22.

51. Piotrowska K, Kubik-Komar A. A comparative analysis of Poaceae pollen seasons in Lublin (Poland). Acta Agrobot. 2012;65(4):39-48. http://dx.doi.org/10.5586/aa.2012.020

52. Puc M. Threat of allergenic airborne grass pollen in Szczecin, NW Poland: the dynamics of pollen seasons, effect of meteorological variables and air pollution. Aerobiologia. 2011;27(3):191-202. http:// dx.doi.org/10.1007/s10453-010-9188-5

53. Voltolini S, Minale P, Troise C, Bignardi D, Modena P, Arobba D, et al. Trend of herbaceous pollen diffusion and allergic sensitisation in Genoa, Italy. Aerobiologia. 2000;16:245-249. http://dx.doi. org/10.1023/A:1007639030473

54. El-Ghazaly G, El-Ghazaly PK, Larsson K, Nilsson S. Comparison of airborne pollen grains in Huddinge and Stockholm, Sweden. Aerobiologia. 1993;9:53-67. http://dx.doi.org/10.1007/BF02311371

55. Clot B. Trends in airborne pollen: an overview of 21 years of data in Neuchâtel (Switzerland). Aerobiologia. 2003;19:227-234. http:// dx.doi.org/10.1023/B:AERO.0000006572.53105.17 
56. Smith M, Emberlin J. A 30-day-ahead forecast model for grass pollen in north London, United Kingdom. Int J Biometeorol. 2006;50:233242. http://dx.doi.org/10.1007/s00484-005-0010-y

57. Ianovici N, Juhasz M, Kofol-Seliger A, Sikoparija B. Comparative analysis of some vernal pollen concentrations in Timisoara (Romania), Szeged (Hungary), Novi Sad (Serbia) and Ljubljana (Slovenia). Not Bot Horti Agrobot Cluj Napoca. 2009;37(2):49-56.

58. Jato V, Rodriguez-Rajo FJ, Seijo MC, Aira MJ. Poaceae pollen in Galicia (N.W. Spain): characterisation and recent trends in atmospheric pollen season. Int J Biometeorol. 2009;53:333-344. http://dx.doi.org/10.1007/ s00484-009-0220-9

59. Davies RR, Smith LP. Forecasting the start and severity of the hayfever season. Clin Allergy. 1973;3:26-30. http://dx.doi. org/10.1111/j.1365-2222.1973.tb01332.x

60. Rantio-Lehtimäki A, Koivikko A, Kupias R, Makinen Y, Pohjola A. Significance of sampling high of airborne particles for aerobiological information. Allergy. 1991;46:68-76. http://dx.doi. org/10.1111/j.1398-9995.1991.tb00545.x

61. Rapiejko P, Lipiec A, Wojdas A, Jurkiewicz D. Threshold pollen concentration necessary to evoke allergic symptoms. Int Rev Allergol Clin Immunol. 2004;10(3):91-94.

62. Rodriguez-Rajo FJ, Jato V, Aira JM. Pollen content in the atmosphere of Lugo (NW Spain) with reference to meteorological factors (1999-2001) Aerobiologia. 2003;19:213-225. http://dx.doi. org/10.1023/B:AERO.0000006527.12928.26

63. Kiotseridis H, Cilio CM, Bjermer L, Tunsäter A, Jacobsson H, Dahl A. Grass pollen allergy in children and adolescents-symptoms, health related quality of life and the value of pollen prognosis. Clin Transl Allergy. 2013;3:19. http://dx.doi.org/10.1186/2045-7022-3-19

64. Erbas B, Chang JH, Dharmage S, Ong EK, Hyndman R, Newbigin $\mathrm{E}$, et al. Do levels of airborne grass pollen influence asthma hospital admissions? Clin Exp Allergy. 2007;37:1641-1647. http://dx.doi. org/10.1111/j.1365-2222.2007.02818.x

65. de Weger LA, Beerthuizen T, Gast-Strookman JM, van der Plas DT, Terreehorst I, Hiemstra PS, et al. Difference in symptom severity between Poaceae early and late grass pollen season in patients with seasonal allergic rhinitis. Clin Transl Allergy. 2011;1(1):18. http:// dx.doi.org/10.1186/2045-7022-1-18

66. Garcia-Mozo H, Galan C, Alcazar P, Diaz de la Guardia C, NietoLugilde D, Recio M, et al. Trends in grass pollen season in southern Spain. Aerobiologia. 2010;26:157-169. http://dx.doi.org/10.1007/ s10453-009-9153-3

67. Albertine JM, Manning WJ, DaCosta M, Stinson KA, Muilenberg ML, Rogers CA. Projected carbon dioxide to increase grass pollen and allergen exposure despite higher ozone levels. PLoS ONE. 2014;9(11):e111712. http://dx.doi.org/10.1371/journal.pone.0111712

\section{Zależność pomiędzy stężeniami ziaren pyłku Poaceae a czynnikami meteorologicznymi w latach 2000-2010 w mieście Timisoara w Rumunii}

\section{Streszczenie}

Praca przedstawia wyniki analizy sezonów pyłkowych Poaceae w latach 2000-2010 w mieście Timisoara w Rumunii. W badanym okresie stężenie ziaren pyłku Poaceae w powietrzu było wysokie. Najdłuższy sezon pyłkowy zanotowano w roku 2000. Obserwowano tendencję wzrostowa w sumach rocznych pyłku traw. Okres, w którym suma ziaren pyłku Poaceae przekraczała wartość progową, wynosząca 30 ziaren $/ \mathrm{m}^{3}$, trwał od 9 do $46 \mathrm{dni}$. Analiza dynamiki sezonów pyłkowych Poaceae na tle czynników meteorologicznych wykazała korelację dodatnią pomiędzy sumami ziaren pyłku Poaceae a temperaturą i usłonecznieniem. Korelację ujemną stwierdzono pomiędzy sumami ziaren pyłku a średnią dobową wilgotnością względną powietrza, ciśnieniem atmosferycznym oraz opadami atmosferycznymi. Zastosowano analizę regresji wielokrotnej, aby określić, jaką część całkowitej zmienności sum ziaren pyłku Poaceae można wyjaśnić parametrami meteorologicznymi. Współczynnik determinacji wahał się od 0.245 do 0.460 . Wykazano negatywny wpływ temperatury, wiatru, wilgotności względnej i opadów na stężenie pyłku w powietrzu. Optymalne warunki do pylenia Poaceae występują późną wiosną i wczesnym latem. Pyłek traw jest jednym z głównym aeroalergenów w Rumunii. 